\title{
BRIEF NOTES: Searching for Affirming Notions of (African) Manhood in the Paean in Praise of the 'Ěšet Hayil? One African Woman's Response to Joel K. T. Biwul's Article, "What is He doing at the Gate?"
}

Madipoane Masenya (ngWan’a MPHahlele) (UNiSA)

\begin{abstract}
The article challenges the "hi-jacking" of a paean in praise of a female to serve a male agenda. It responds to Biwul's article in OTE 29(1) 2016 in which the author attempts to "resuscitate" what he regarded as the traditionally forgotten male figure in his reading of Proverbs 31:10-31. This article pushes the point that women facing androcentric texts are in need of reading themselves into places where they are not perceived to be present.
\end{abstract}

KEY WORDS: 'ēšet hayil, male figure (read: ba'al), women, household manager, family, (African) manhood, Yehud.

\section{A INTRODUCTION}

This brief note, responding to an article by Joel K. T. Biwul ("What Is $\mathrm{He}$ Doing at the Gate? Understanding Proverbs 31:23 and Its Implications for Responsible Manhood in the Context of Contemporary African Society" in Old Testament Essays 29/1 (2016), ${ }^{1}$ is framed by two quotations:

To join those who seek wisdom, women are thereby forced to include ourselves, where we have been, by tradition, excluded. We must write ourselves into the text. Modern women's appropriation of this tradition represents an example of how women, when facing the androcentric biblical text- to say nothing of patriarchal religious and social

\footnotetext{
* Madipoane Masenya (ngwan'a Mphahlele), "Searching for Affirming Notions of (African) Manhood in the Paean in Praise of the 'Eshet Hayil? One African Woman's Response to Joel K. T. Biwul's Article on, What is He doing at the Gate?" OTE 29/2 (2016): 360-369, doi: http://dx.doi.org/10.17159/2312-3621/2016/v29n2a10

1 Joel K. T. Biwul, "What Is He Doing at the Gate? Understanding Proverbs 31:23 and Its Implications for Responsible Manhood in the Context of Contemporary African Society", OTE 29 (2016): 33-66. DOI: http://dx.doi.org/10.17159/23123621/2016/v29n1a4.
} 
Masenya, "Brief Notes: Response to Biwul," OTE 29/2 (2016): 360-369 361

institutions - must make new patterns, must read ourselves into places we were not previously envisioned as inhibiting. ${ }^{2}$ (Emphasis-M.M.)

My observation is that, in this period of Jewish history, women were a powerful threat to the kyriarchal status quo. Marriages with women who were deemed foreign (symbolized by Woman Stranger) could disrupt the socio-economic, socio-political and socio-religious lives of the 'true' Jews and ultimately of the whole nation because a family is a basic unit of each society. The emphasis on good and bad women and the book's ending with a poem in praise of an ideal woman thus makes sense in this context. Men had to strive for the ideal (whatever it stood for) to maintain the status quo. ${ }^{3}$

In his article Joel K. T. Biwul is concerned about what could be designated as problematic notions of masculinities in our African contexts. He takes pains to elevate the male figure in his reading of a paean which was authored to praise not an ordinary woman, but the Woman of Worth. ${ }^{4}$ In Biwul's view, the husband (read: the ba'al)) of the Woman of Worth, even more than the Woman of Worth herself, is to receive praise than has traditionally been the case. Such a praise is not only linked to the important role the male figure is supposedly playing as one of the elders sitting at the gates of Israel's cities, but also to his invisible role as the one behind the successes of the Woman of Worth. In constructing a masculine visibility in Proverbs 31 Biwul wants men in his Nigerian context to emulate the example provided by the husband of the Woman of Worth, ${ }^{5}$ because in his view African men in his context have neglected their manly responsibilities in their households.

2 Linda, Day, "Wisdom and the feminine in the Hebrew Bible," in Engaging the Bible in a Gendered World: An Introduction to Feminist Biblical Interpretation in Honor of Katharine Doob Sakenfeld, ed. Linda Day \& Carolyn Pressler (Louisville/London: Westminster Press, 2006), 126.

Madipoane Masenya (ngwan'a Mphahlele), How Worthy is the Woman of Worth: Rereading Proverbs 31: 10-31 in African-South Africa (New York: Peter Lang, 2004), 99.

4 So rare is the designation of 'éšet hayil in the Hebrew Bible that it appears only four times in the rest of the corpus. And Proverbs 31:10-31 is the only text in the whole Christian Bible that stipulates the qualities of a virtuous woman. In the case of the "ish (man) of the Woman of Worth, the problematic word " $b a$ 'al" (master) is used to designate the man or spouse attached to such a powerful figure.

5 The use of words of English words like husband and wife appear problematic if we note with Pressler: "The Older Testament does not offer a single view of marriage, much less a single view of the family. Biblical Hebrew does not have a noun "marriage" or a verb 'to marry'; it rarely uses terms that explicitly refer to marital status ('husband' or 'wife'). Instead, the texts speak of a man 'taking' or 'having' a woman" Carolyn Pressler, "The 'Biblical View' of Marriage," in An Introduction to Feminist Biblical Interpretation in Honor of Katharine Doob Sakenfeld: Engaging the 
Biwul engages the paean by addressing four aspects. As a point of departure, he explains the etymology of the Hebrew word for "gate" or "city gates" in the Old Testament. Thereafter, he spells out the functions of the gate according to what he refers to as "the Old Testament understanding" of the concept. Thirdly, Biwul identifies the credentials which qualified Israelite men to sit at the gate and lastly, the author draws some implications from his findings about manhood in the paean of Proverbs 31:10-31 for contemporary (Nigerian) African men with regard to their responsibilities as husbands and fathers in their families.

\section{B COMPETING OR COMPLEMENTING EACH OTHER?}

Some years ago, I was invited by one of the historical Pentecostal churches to address men about what the expectations of married women were from their husbands. I counted it a real privilege as I seldom received such invitations. As part of the teaching which I offered to the male audience that evening, I, like Biwul in his article, employed the paean of the Woman of Worth in Proverbs 31:10-31 to challenge the African Christian men in the audience: I wanted them to take their cue from the Woman of Worth and make a positive contribution to the welfare of their families. I compared the various activities reflected as being performed by the Woman of Worth to that of the husband who is portrayed as basically sitting at the gates. My conclusion to this comparison was that the one who actually revealed the qualities of leadership in the household was the woman. ${ }^{7}$ With hindsight, I need to confess that I was actually pitting the 'éset hayil against her husband, albeit perhaps not intentionally.

It will not be an exaggeration to argue that the motivation behind the origins of Biwul's article was based on the comparison between the male and female figures who, among other characters, ${ }^{8}$ feature in the paean of Proverbs 31: 10-31. Elsewhere Biwul notes:

Bible in a Gendered World, ed. Linda Day and Carolyn Pressler (Louisville/London: Westminster John Knox, 2006), 206.

6 Biwul, "What is he doing," 37.

7 Such a view is embedded in what unsettles Biwul ("What is he doing," 35) when he notes: "The projection of the female figure in this poem gives the impression that she is more responsible in contrast to the male figure personified as her husband. This argues for her being praised, extolled, honoured, and dignified above him."

8 The male figure who receives relatively little attention in this paean, is not the only one who faces such an interpretive plight if we, like Biwul opt to view it as such. Her children and her servant girls are also mentioned in passing. If we posited a preexilic setting as Biwul does in his article, we could even add more missing members within the extended families as in that setting, the male figure in the poem may not even have remained the patriarch of the household. His father could have assumed that role. As many feminist scholars of Proverbs have argued, the Sitz Im Leben 
Masenya, "Brief Notes: Response to Biwul," OTE 29/2 (2016): 360-369 363

This statement provoked my thinking and motivated me to seek further understanding about the role of the male figure in this poem vis-à-vis his wife who is presented as a woman of acclaimed virtue in the society of her day. Following this motivation, I discovered from careful study that scholarship has consistently concentrated attention and joined in the traditional praise of the female figure to the neglect of the significant role of the male figure. ${ }^{9}$ (Emphasis-M.M.)

As a matter of fact, Biwul does more in this article than what I did then. Concerned that through the years, undue praise and focus has been more on the Woman of Worth rather than on her husband, Biwul sets out to resuscitate this "lost" human being (identity?) in the paean. Biwul thus determined to take a bold step to search for affirming notions of manhood ironically in a paean which was written to laud a woman, and not a man. He was intent on identifying those elements in the paean which, in his view, invite the paean's present day readers, especially African (read: Nigerian) men, to get their cue from the man who, even more than the wife, must receive the praise:

The aim of the study is situated in its thesis that suggests that, given the Jewish social context for familial relationship, the architect behind the strength, achievements, and public recognition accredited to this female figure is her husband, but who is, unfortunately, not recognised as such by interpreters."10 (Emphasis-M.M.)

But a question arises as to the kind of Israelite/Jewish context surmised here. Over-against Biwul's choice in favour of a pre-exilic date for Proverbs 31:10-31, I argue in favour of a date that fits an early post-exilic setting. ${ }^{11}$ However, irrespective of the dating which may be posited for the book, throughout the history of Ancient Israel, Israelite society always had gendered roles. Despite the patriarchal contexts in which they operated, Israelite women

depicted in Proverbs, and in particular, Proverbs 31:10-31, is that of post-exilic Yehud in which monogamy seems to have been the order of the day.

9 Biwul, "What is he doing," 35.

10 Biwul, "What is he doing," 35.

11 According to Carole Fontaine, the poem of Proverbs 31:10-31 expresses the great value put on the family as the significant social and religious unit within Israelite society, both in the pre-monarchical and in the post-exilic Judaism from which this composition probably comes. Carole Fontaine, "Proverbs," in Harper's Bible Commentary (ed. James L. Mays, San Francisco: Harper and Row, 1988), 184; (cf. also Ellen L. Lyons, "A note on Proverbs 31:10-31" in The Listening Heart: Essays in Wisdom and the Psalms in Honor of Roland E. Murphy, ed. Kenneth G. Hogland (Sheffield: Sheffield Academic Press, 1987), 241; Claudia V. Camp, Wisdom and the Feminine in the Book of Proverbs (Sheffield: JSOT, 1985), 250-254. For more information of the early post-exilic dating of the paean, read Masenya (ngwan'a Mphahlele), How Worthy is the Woman of Worth, 72-75. 
in biblical Israel performed no mean jobs. In the view of Carol Meyers for example, the pioneering conditions during the settlement period enabled some form of egalitarianism between women and men. ${ }^{12}$ Through all of its history the economy of Israel relied solidly on agriculture. The hard work of farming families was pivotal for the successful running of a family household. As both a biological and economic unit, the household produced and processed all the food, clothing and implements, (except metal items), which were necessary for the people's survival in the Palestinian highlands. ${ }^{13}$ A similar situation emerges in the portrait of the 'éset hayil in Proverbs 31:10-31. In the view of Tamara Eskenazi, the preceding observation could be evidence for the resemblances between prevailing conditions both in the settlement period and in the postexilic period. ${ }^{14}$

Persuaded by the notion that behind the success of every woman there is a man, the argument would be with regard to the the 'éset hayil that if she achieves success, it is because of a supportive man behind her. For this reason Biwul can thus say

It [the article] draws attention to the civilised and humane personality of this male figure who serves as the architect of the achievements and public praise of his wife given the patrilocal and patriarchal context of ancient Israel. ${ }^{15}$

A few questions arise and the following observations can be made though. Firstly, in a heterosexual marriage context, are the two not supposed to be viewed as one? Are a husband and a wife not to exude a spirit of mutuality and complementarity rather than a competitive spirit? If the former should hold, as I think it should, the alleged support that the Woman of Worth received/receives from her husband would not have come as a surprise, particularly also persuaded by the African spirit of Botho/Ubuntu, family and corporeality. If any marriage or family is to flourish, both husband and wife should jointly work together for the welfare of such institutions. In our African contexts, a human being is a human being because of other human beings. Such a Botho spirit, the spirit of hesed (cf. the spirit consistently displayed by Boaz, the 'iš gibbôr, in the book of Ruth in the Hebrew Bible) will enable men to refuse to be threatened by the successes of their wives even if male successes may seem to pale in significance when compared to their wives. ${ }^{16}$

12 Carol L. Meyers, "Everyday Life: Women in the Period of the Hebrew Bible," in $W B C, 246$

13 Meyers, "Everyday Life," 246

14 Tamara C. Eskenazi, "Out from the Shadows: Biblical Women in the Postexilic Era," JSOT 54 (1992): 33.

15 Biwul, "What is he doing," 33

16 Elsewhere, Thomas McCreesh argues that the activities of the husband of the Woman of Worth as compared to those of his wife pale in significance. Thomas 
Secondly, the male figure in the paean of Proverbs 31:10-31 is not the only one who receives less coverage when compared to the Woman of Worth. The children and the servant girls are also mentioned in passing by the poet. It thus becomes curious why Biwul chose not to show empathy with these other "marginalised" characters in the paean. Also, the 'êset hayil's role as a mother is basically missing in a context which, like in many African contexts, set great store by the role of women as mothers. The observation that the poet foregrounds the 'ěšet hayil and gives her more coverage than all the other equally important members of her household ${ }^{17}$ is simply because the poem is not in praise of all the members of the household including the head of the household. The poem of Proverbs 31:10-31 is a paean deliberately coined to praise not an ordinary woman, but a phenomenal woman, a woman of substance, a Woman of Worth. The important feature that is highlighted is her capacity to manage the various activities of her household efficiently. Such a role was critical during this time in Judaean history when, as already noted with Camp, the family regained power as the locus of divine authority.

Thirdly, the view that pities the 'êset hayil vis-à-vis her husband fails to appreciate the fact that "women in the book of Proverbs are not chattel, but a force to reckon with who from the viewpoint of the sage could either make a man or break him." ${ }^{, 18}$ More than in any book of the Hebrew Bible, in the Book of Proverbs, female imagery abounds. The book of Proverbs is also enveloped by a coda which elevates women, be it Woman Wisdom, Woman Stranger and Woman Folly in the opening Instruction (Proverbs1-9); or the Queen Mother, the mother of king Lemuel in the female Instruction (Proverbs 31:1-9); or even more importantly for our present investigation, the Woman of Worth in the paean of Proverbs 31:10-31. It was during the post-exilic period, in the absence of the monarchy and the Jerusalem temple, that the family regained

McCreesh, "Wisdom as Wife: Proverbs 31:10-31," Revue Biblique 92 (1985), 27-28. As I argue in this article, such a line of argument unfortunately misses to appreciate the nature of the paean of Proverbs 31:10-31. The sage, informed by the highly regarded institution of family in Yehud, one in which the woman in her role as household manager became highly valued, deliberately chose to laud the Woman of Worth rather than what her husband was doing at the gate, important as his role could have been there at the gate. For more details on the important functions that Israelite men performed at the gates of Israel, see, Biwul, "What Is He Doing," 33-60.

17 See Masenya (ngwan'a Mphahlele), How Worthy is the Woman of Worth, 101: "The woman defines and identifies the house in the manner analogous to the more usual reference to the בת אב (house of father), cf. the repeated reference to בתח, ("her household', vss. 15, 21 and 27). This however, does not imply that the house no longer belonged to the man or father, it only shows the power which she had with regard to household activities."

18 Phyllis A. Bird, "Images of woman in the book of Proverbs" in Religion and Sexism: Images of Woman in the Jewish and Christian Traditions, ed. Rosemary Radford Ruether (New York: Simon and Schuster, 1974), 57. 
significance as the locus of divine authority. ${ }^{19}$ Does it occasion any surprise then that a "woman," particularly in her role as a husband's wife and as a household manager, would be given prominence in the book of Proverbs? The elevation of a woman, especially as household manager, rather than a man, in the paean of Proverbs 31:10-31, needs to be understood against the preceding background. $^{20}$

An observation made in a previous study is still on target:

My observation is that, in this period of Jewish history, women were a powerful threat to the kyriarchal status quo. Marriages with women who were deemed foreign (symbolized by Woman Stranger) could disrupt the socio-economic, socio-political and socio-religious lives of the 'true' Jews and ultimately of the whole nation because a family is a basic unit of each society. The emphasis on good and bad women and the book's ending with a poem in praise of an ideal woman thus makes sense in this context. Men had to strive for the ideal (whatever it stood for) to maintain the status quo. ${ }^{21}$

As already observed, the 'éšet hayil was/is the household manager par excellent in Proverbs 31:10-31. In Africa though, if I understand Biwul's argument correctly, men are household managers. To this point we now turn.

\section{WHO ARE THE MANAGERS OF AFRICAN HOUSEHOLDS?}

Biwul un-problematically" "transfers" the household manager responsibilities of the 'êšet hayil to her husband and then to African men in general, as in his view, "[t]his is necessary because in Africa, household responsibilities rest on the shoulders of the male figure who is both husband and father; and far more, an uncle and kinsman as well." 23

One can, however, argue the case differently. Although men as fathers, husbands, uncles and kinsmen play a significant role in providing for and protecting their families, it would not be correct to argue "that household responsibilities rest on the shoulders of the male figure who is both husband

19 Camp, Wisdom and the Feminine in the Book of Proverbs, 69-147.

20 Meyers, "Everyday Life," 246; Eskenazi, "Out from the Shadows," 33; Masenya (ngwan'a Mphahlele), "The Dissolution of the Monarchy, the Collapse of the temple and the 'elevation' of Women in the Post-Exilic Period: Any Relevance for African Women's Theologies?" OTE 26 (2013): 137-153.

21 Masenya (ngwan'a Mphahlele), How Worthy is the Woman of Worth, 99.

22 In line with his agenda to search for affirming notions of manhood in a poem which elevates a woman, it also comes as no surprise that Biwul is able to easily transfer a trait of efficient house management — one that so conspicuously defines the Woman of Worth - to her husband who sits at the gate.

23 Biwul, "What is he doing," 37. 
Masenya, "Brief Notes: Response to Biwul," OTE 29/2 (2016): 360-369 367

and father; and far more, an uncle and kinsman as well."24 I have argued elsewhere $^{25}$ that in the Sepedi/Northern Sotho African culture, lapa ke la mosadi, literally, a household in essence belongs to a woman. A married woman in an African household may not be designated as head of a household. However, just like the 'éšet hayil, a woman, even more than a man, is especially conversant (or, supposed to be conversant) with all the nitty gritty that happens in the household. Subsequently, one could reach a safe conclusion that in our African contexts, women, rather than men, have historically and even up to today, remained household managers. This particular role has unfortunately come under pressure due to many a young African woman joining the public sphere of work today, necessitating her husband to also take an active role in the managing of the household. Women have become empowered in the public sphere, and men should be empowered to share in the chores of the household.

In my experience, in those instances where the husband played no role in the managing of the household, the death of his wife causes a huge disruption. It is thus no surprise when the husband, not even after the mourning period of his wife has finished, starts to search for a new household manager. On the other hand, it is also common place to find many African widows who have run their families all by themselves without any male intervention for many years. The household managers of patriarchal African households, those who also usually receive the short end of the stick, are thus women.

\section{CONCLUSION}

In my view, in Biwul's article he does an excellent job by revealing that Israelite men who sat at the gates were not loitering as some of the African male readers of the poem seem to argue. ${ }^{26}$ Such readers miss the point behind the significant role which the historical contexts of the production of the texts have for our understanding of these today. The approach adopted by Biwul in unpacking the significance of the gates in that history thus enables him to deconstruct problematic literalistic readings of biblical texts, readings which have historically been used to marginalise others including women.

His commitment to constructing liberating masculinities in a context where some men choose to lead parasitic and detached lives, deliberately ignoring their family responsibilities, is a welcome breath in the scholarly gender-identified biblical hermeneutics.

However, Biwul's choice of one of the relatively few texts in the Hebrew Scriptures which highlight the role of women in communities, to not only

24 Biwul, "What is he doing," 37.

25 Masenya (ngwan'a Mphahlele), How Worthy is the Woman of Worth, 146.

26 Biwul, "What is he doing," 36. 
address a male agenda, but also to water down the agency of a woman by arguing that the glory due to her, in actual fact belongs to a man, is problematic. After all what this Woman of Worth does, having excellently revealed the manifold activities of wisdom, one can but only agree with the paean of Proverbs 31:10-31, the one to be praised is neither her children or her slave girls, nor her ba'al, but the 'éšet hayil herself. Hence,

Give her of the fruits of her hand

And let her own works praise her at the gates. (Proverbs 31:31)

\section{BIBLIOGRAPHY}

Biwul, Joel K. T. "What Is He Doing at the Gate? Understanding Proverbs 31:23 and Its Implications for Responsible Manhood in the Context of Contemporary African Society." Old Testament Essays 29 (2016): 33-60. doi: http://dx.doi.org/10.17159/2312-3621/v29n/a4

Camp, Claudia V. Wisdom and the Feminine in the Book of Proverbs. Sheffield: JSOT, 1985.

Bird, Phyllis A. "Images of woman in the book of Proverbs." Pages 41-60 in Religion and Sexism: Images of Woman in the Jewish and Christian Traditions. Edited by Rosemary Radford Ruether. New York: Simon and Schuster, 1974.

Day, Linda. "Wisdom and the feminine in the Hebrew Bible." Pages 114-127 in Engaging the Bible in a Gendered World: An Introduction to Feminist Biblical Interpretation in Honor of Katharine Doob Sakenfeld. Edited by Linda Day \& Carolyn Pressler, Luisville and London: Westminster Press, 2006.

Eskenazi, Tamara C. "Out from the Shadows: Biblical Women in the Postexilic Era." Journal for the Study of the Old Testament 54 (1992): 25-43.

Fontaine, Carole. "Proverbs." Pages 495-517 in Harper's Bible Commentary. Edited by James. L. Mays. San Francisco: Harper and Row, 1988.

Lyons, Ellen L. "A note on Proverbs 31:10-31." Pages 237-245 in The Listening Heart: Essays in Wisdom and the Psalms in Honor of Roland E. Murphy. Edited by Kenneth G. Hogland. Sheffield: Sheffield Academic Press, 1987.

McCreesh, Thomas. "Wisdom as Wife: Proverbs 31:10-31." Revue Biblique 92 (1985): 27-28

Meyers, Carol L. "Everyday Life: Women in the Period of the Hebrew Bible." Pages 248-249 in Women's Bible Commentary. Edited by Carol A. Newsom and Sharon H. Ringe. Louisville, KY: Westminster/John Knox, 1992.

Madipoane Masenya (ngwan'a Mphahlele). "The Dissolution of the Monarchy, the Collapse of the temple and the 'elevation' of Women in the PostExilic Period: Any Relevance for African Women's Theologies?” Old Testament Essays 26 (2013): 137-153. 
Masenya, "Brief Notes: Response to Biwul,” OTE 29/2 (2016): 360-369 369 . How Worthy is the Woman of Worth: Rereading Proverbs 31: 1031 in African-South Africa. New York: Peter Lang, 2004.

Carolyn Pressler, “The 'Biblical View' of Marriage.” Pages 200-2011 in An Introduction to Feminist Biblical Interpretation in Honor of Katharine Doob Sakenfeld: Engaging the Bible in a Gendered World. Edited by Linda Day and Carolyn Pressler. Louisville and London: Westminster John Knox, 2006.

Prof. Madipoane Masenya (ngwan'a Mphahlele) teaches within the Department of Biblical and Ancient Studies at the University of South Africa. Email: Masenmj@unisa.ac.za. 